\title{
Por entre lágrimas e rastros de sangue: as dores e angústias representadas pela violência contra a mulher em olhos d'água, de Conceição Evaristo
}

\author{
Between tears and blood traces: the pains and anguishes represented for violence against women in olhos \\ d'água of Conceição Evaristo
}

\section{Luciane de Lima Paim}

\author{
Patrini Viero Ferreira
}

\section{Rosani Úrsula Ketzer Umbach}

Universidade Federal de Santa Maria - UFSM - Santa Maria - Rio Grande do Sul - Brasil

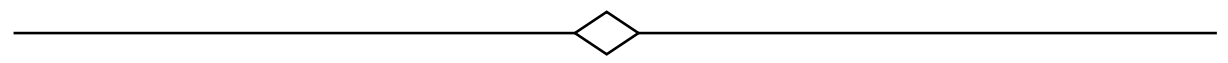

Resumo: Segundo as fontes midiáticas atuais, como jornais e redes sociais, aos três dias do mês de fevereiro de 2019, já haviam sido contabilizados 109 casos de feminicídios no Brasil. Nesse sentido, se as mazelas do patriarcado ainda eram motivo de discussões e dúvidas para a sociedade, com tais situações fica evidente que nós mulheres ainda somos reféns de um grupo que vê e materializa a mulher como um objeto, jamais como um sujeito, nos tornando, assim, parte das minorias excluídas pelo patriarcado. Para tanto, relacionar esse tema com a literatura brasileira torna-se uma ferramenta de resistência. Ferramenta essa que é capaz de levar para todos os espaços e para todos os grupos sociais a voz e as histórias de mulheres que tiveram a vida marcada por dor, violência e sofrimento. Conceição Evaristo, em grande parte do seu acervo literário, faz questão de representar, através de suas personagens, as histórias dessas mulheres. Assim, o objetivo desse estudo é identificar por quais tipos de violência física passam as personagens apresentadas em Olhos d'água (2014). Metodologicamente, foram analisados excertos da narrativa que reforçam o que já foi mencionado por Beauvoir, Butler, Spivak, Bourdie, Scott, Freyre, Tiburi, entre outros, sobre violência contra mulher, desigualdade de gênero, discriminações raciais e patriarcalismo, visto que não há como desvincular tais temáticas do tema central. Por fim, conclui-se que como nessa pesquisa a mulher é vista como vítima, afirma-se que das personagens apresentadas pela autora e selecionadas para o estudo, todas sofrem algum tipo de violência.

Palavras-chave: Violência contra a mulher. Olhos d'água. Conceição Evaristo. Contos brasileiros.

Abstract: According to the sources current media such as newspapers and social networks on the three days of February 2019, 109 cases of femicide had already been reported in Brazil. Therefore, if patriarchy were still a matter of discussion and doubt for society, with such situations are evident that women are still a group that sees and materializes a woman as an object, never as a subject, thus making us part of minorities excluded by patriarchy. Brazil becomes a way of resistance. This way is capable of taking for all spaces and for all social groups the voice and stories of women who had their lives marked by pain, violence and suffering. Conceição Evaristo, for the most part of his literary collection, makes a point of representing, through her characters, the stories of these women. Thus, the purpose of this study is to identify by what types of physical violence pass the characters presented in Olhos d'agua (2014). Methodologically, excerpts from the narrative were analyzed that reinforce what has already been mentioned by Beauvoir, Butler, Spivak, Bourdie, Scott, Freyre, Tiburi, among others, about violence against women, gender inequality, racial discrimination and patriarchalism, since there is no way to disconnect such purposes from the central purpose. Finally, it is concluded that as in this research the woman is seen as a victim, it is stated that of the characters presented by the author and selected for the study, all suffer some kind of violence

Keywords: Violence against women. Olhos d'agua. Conceição Evaristo. Brazilian literature. 


\section{Introdução}

Infelizmente, ainda hoje, existem muitos discursos que priorizam a voz do homem e menosprezam a voz da mulher, fazendo com que nossa sociedade regresse há épocas em que o patriarcalismo prevalecia e comandava a nação. Nesse sentido, a luta feminina por seu lugar e sua voz dentro de uma sociedade calcada em modelos patriarcais, se faz diariamente, com muita resistência, coragem e força, pois são dias nebulosos para quem sabe o que é lutar para não ser banida, violentada e silenciada.

Assim, para essa pesquisa, buscou-se enaltecer a voz de uma das mulheres que está deixando sua marca na literatura brasileira: Maria da Conceição Evaristo de Brito, conhecida popularmente por Conceição Evaristo. A escrita dessa autora é marcada por um posicionamento que busca destacar a sua vivência de mulher negra na sociedade brasileira. Sua obra em prosa é constituída por excluídos sociais, favelados, prostitutas, lavadeiras, empregadas domésticas, meninos(as) de rua, desempregados, bêbados.

Conceição Evaristo tem uma vida de muita luta e muitas glórias, ela nasceu em Belo Horizonte, em 29 de novembro de 1946. De origem humilde, migrou para o Rio de Janeiro na década de 1970. De acordo com Duarte, a escolha pelo curso de Letras decorre da paixão que, desde cedo, dedica à literatura: "na adolescência Jorge Amado, José Lins, Carolina Maria de Jesus e tantos outros; mais tarde, Graciliano, Rosa, Drummond, Bandeira e, também Solano Trindade, Abdias do Nascimento, Adão Ventura." (DUARTE, 2007, p. 23). Seus primeiros poemas foram publicados nos Cadernos Negros, número 13. Hoje, ela é Mestre em Literatura Brasileira pela PUC do Rio de Janeiro, com a dissertação Literatura Negra: uma poética de nossa afrobrasilidade (1996), e Doutora em Literatura Comparada na Universidade Federal Fluminense, com a tese Poemas malungos, cânticos irmãos (2011), na qual estuda as obras poéticas dos afro- brasileiros Nei Lopes e Edimilson de Almeida Pereira em confronto com a do angolano Agostinho Neto.

Olhos D’Água (2014), corpus dessa pesquisa, é um livro de contos, vencedor do prêmio Jabuti, nessa categoria, em 2015. Nessa obra, a autora sacramenta, com uma linguagem sutil e poética, a pluralidade da existência humana, como é mencionado na introdução da obra. No prefácio da $1^{\underline{a}}$ edição da obra, Heloisa Toller Gomes apresenta algumas das personagens:

Sem sentimentalismos facilitadores, mas sempre incorporando a tessitura poética à ficção, os contos de Conceição Evaristo apresentam uma significativa galeria de mulheres: Ana Davenga, a mendiga DuzuQuerença, Natalina, Luamanda, Cida, a menina Zaíta. Ou serão todas a mesma mulher, captada e recriada no caleidoscópio da literatura em variados instantâneos da vida? Diferem elas em idade e em conjunturas de experiências, mas compartilham da mesma vida de ferro, equilibrando-se na "frágil vara" que, lemos no conto "O Cooper de Cida", é a "corda bamba do tempo". Na verdade, essa mulher de muitas faces é emblemática de milhões de brasileiras na sociedade de exclusões que é a nossa. (2011, p. 9-10).

Evaristo traz à tona, na obra supracitada, o que muitas mulheres e homens enfrentam e suportam. $E$ é através de obras como essa que se percebe que Conceição acaba dialogando com autoras de sua época, como Carolina Maria de Jesus, Maria Firmina dos Reis, dentre outras. Durante toda as narrativas a autora consegue explorar como é a vivência de tantas mulheres, crianças e homens que se encontram à margem do local pré-estabelecido. São contos que abordam histórias de todas as formas: mulheres estupradas, espancadas, perseguidas, acoadas; crianças assassinadas, vivendo na miséria, passando fome e frio; são homens espancados, envenenados, violentados. Como Evaristo mesmo afirma, "são ficções que se cruzam com nosso mundo, nossas vivências, são as escrevivências de um povo que até pouco tempo não tinha voz, não era reconhecido e tinha a vida renegada ao sofrimento e à miséria." (EVARISTO, 2018) 
A obra engloba quinze contos: "Olhos d'água"; "Ana Davenga"; "Duzu-Qurença"; "Maria”; "Quantos filhos Natalina teve?"; "Beijo na face"; "Luamanda"; "O cooper de Cida"; "Zaíta esqueceu de guardar os brinquedos"; "Di lixão"; "Lumbiá"; "Os amores de Kimbá"; "Ei, Ardoca"; "A gente combinamos de não morrer"; e "Ayoluwa, a alegria de nosso povo". Desses quinze, nove são histórias de mulheres e, portanto, nessa pesquisa, focando na mulher como vítima da violência física, serão analisados apenas quatro, pois são os únicos que abordam algum tipo de violência física contra as mulheres. Assim, destaca-se que os contos analisados serão: "Duzu-Qurença"; "Maria"; "Quantos filhos Natalina teve?"; e "Luamanda".

\section{Por entre olhos cheios de água e corpos marcados por sangue}

Os três contos analisados são narrados em $3^{\text {a }}$ pessoa, com um narrador onisciente e focam na apresentação da vida de mulheres negras. Além disso, esse narrador adota o ponto de vista da personagem, isto é, os leitores são conduzidos pelo olhar e sentimentos da personagem em vários momentos. Esse recurso permite maior aproximação das sensações da protagonista, sensibilizando o leitor para os acontecimentos, sobretudo, os que cercam a criança e sua vida de agruras no prostíbulo. A câmera, como aponta a argumentação crítica do artigo, demonstraria distanciamento do narrador, ou seja, um olhar observador, limitando-se a descrever os acontecimentos de fora. O que ocorre neste conto é a aproximação dessas sensações e não o distanciamento.

Ambas as histórias fazem parte de um contexto social de exclusão e discriminação social, onde as mulheres negras eram vistas como inferiores aos demais membros da sociedade. Duzu aparece, primeiramente, como uma mendiga pedindo esmolas nas ruas da cidade: "Quando se fartou deste sonho, arrotou satisfeita, abandonando a lata na escadaria da igreja e caminhou até mais adiante, se afastando dos outros mendigos." (EVARISTO, 2014, p. 31) Maria surge como uma empregada doméstica que estava indo para casa com as sacolas dos restos de comida que sobrara da casa da patroa: "No dia anterior, no domingo, havia tido festa na casa da patroa. Ela levava para casa os restos. O osso do pernil, as frutas que tinham enfeitado a mesa. Ganhara as frutas e uma gorjeta." (EVARISTO, 2014, p. 40) Natalina surge como uma mãe feliz pela gravidez, apesar de ter abortado vários filhos e, posteriormente, servir como barriga de aluguel para o casal de patrões: "Ela sorriu feliz. Era a sua quarta gravidez, e o seu primeiro filho. Só seu. De homem algum, de pessoa alguma. Aquele filho ela queria, os outros não. [...] As outras barrigas ela odiara. [...] $O$ estorvo que ela carregava na barriga faria feliz o homem e a mulher que teriam um filho que sairia dela." (EVARISTO, 2014, p. 43-48); e, por fim, Evaristo apresenta Luamanda, uma eterna apaixonada, que não cansava de procurar o amor, mesmo este lhe deixando com marcas eternas: "É, estava inteirinha, apesar de tantos trambolhões e acidentes de percurso em sua vida-estrada." (EVARISTO, 2014, p. 59)

Essas quatro mulheres apresentadas nos contos de Evaristo fazem parte de uma parcela de mulheres que teve a vida marcada por sofrimento, violência, discriminação e abandono. Duzu, em sua condição atual, é uma mendiga que passa a narrativa toda relembrando sua trajetória, desde o dia que chegou à cidade grande. Ela chegou de outras terrar com o pai, um pescador sonhador que migra em busca de uma vida melhor para sua família. Entretanto, os buracos negros da cidade grande engolem todos os seus sonhos. Logo cedo, ainda menina, Duzu foi obrigada a trabalhar em uma casa de família, com a promessa da patroa de que a menina teria um bom futuro e estudaria, no entanto, a "casa de família" não passava de um prostíbulo, onde Duzu teve sua infância interrompida e acabou entrando ao mundo da prostituição.

É importante ressaltar que Duzu nunca teve escolhas. Ela jamais foi consultada sobre ir morar longe dos pais, sobre querer ficar numa casa com desconhecidos. Nunca teve voz, desde criança foi silenciada e, na vida adulta, não foi muito diferente. 
Duzu, na realidade, havia ido morar em um prostíbulo. Ela via as cenas de sexo entre homens e mulheres e não entendia porque aquilo estava acontecendo ali onde ela morava. Através dessas experiências vivenciadas, Duzu acabou adentrando à vida adulta sem ao menos ter consciência disso. O resultado disso foi o dia em que, pela primeira vez, ela foi vítima de um pedófilo, pois, "Teve um momento em que o homem chamou por ela. Vagarosamente ela foi se aproximando. Ele, em cima da mulher, com uma das mãos fazia carinho no rosto e nos seios da menina." (EVARISTO, 2014, p. 33). Sem saber o que acontecia, porque de ser tratada assim, Duzu permanecia ali, parada, sem reação, tentando entender de que mundo ela estava fazendo parte.

Sobre essa questão do abandono da infância e da introdução à vida adulta, ainda criança, é válido prestarmos atenção sobre o que fala Bourdieu, em $A$ Dominação Masculina (2005), sobre essa dominação de origem patriarcal, pois no caso de Duzu, a dominação masculina privou a infância de uma criança e a violência acabou tornando-se diária na vida dela:

[...] sempre vi na dominação masculina e no modo como é imposta e vivenciada, o exemplo por excelência [...] (da) submissão paradoxal, resultante daquilo que eu chamo de violência simbólica, violência suave, insensível a suas próprias vítimas, que se exerce essencialmente pelas vias [...] simbólicas da comunicação e do conhecimento, ou, mais precisamente, do desconhecimento, do reconhecimento, ou, em última instância, do sentimento. (BOURDIEU, 2005, p. 7)

Sem ter noção alguma do que estava acontecendo, Duzu continuou sua peregrinação pelos quartos da casa, a fim de descobrir o que se passava ali e por que ela via aquelas cenas, cenas de sexo, tão frequentes. O problema foi quando, um dia, em um desses quartos, "[...] o homem estava deitado nu e sozinho. Pegou a menina e jogou na cama. Duzu não sabia ainda o ritmo do corpo, mas, rápida e instintivamente, aprendeu a dançar". (EVARISTO, 2014, p. 33).
Duzu foi estuprada e, mais uma vez, silenciada, pois a voz dela não foi ouvida. Quando a dona do prostíbulo descobriu que o homem havia abusado a menina, ela não deu voz à criança, muito menos viu que aquilo era um estupro. Ela considerou que Duzu gostava do que fazia, e a partir desse dia ou a menina trabalhava como prostituta para ter casa e comida ou ela seria expulsa dali. Sem ter para aonde ir, sem saber o paradeiro dos pais, Duzu só tinha uma escolha, e foi assim que suas brincadeiras de boneca foram substituídas por roupas provocantes, preservativos e homens nus violentando seu corpo.

Sobre as cenas de sexo envolvendo Duzu é importante retomarmos o papel do narrador, pois, mais uma vez, ele usa de seus recursos linguísticos inclinados a demonstrar que a personagem era conivente com a vida que levava, e, mais ainda, que ela gostava de praticar tais ações:

[...] Duzu viu várias vezes homens dormindo em cima de mulheres. Homens acordados em cima das mulheres. Homens mexendo em cima das mulheres. Homens trocando de lugar com mulheres. Gostava de ver aquilo tudo. [...]

[...] Ele em cima da mulher, com uma das mãos fazia carinho no rosto e nos seios da menina. Duzu tinha gosto e medo. Era estranho, mas era bom. [...] (EVARISTO, 2011, p. 33)

A partir dessa visão estereotipada e parcial do narrador, fica evidente uma tentativa dele de conduzir o leitor a determinados pré-conceitos e julgamentos sobre a personagem. Outro ponto importante de ressaltar é que nesse sentido, em nenhum momento, há uma oportunidade da personagem se expressar e apresentar os seus reais sentimentos sobre o que estava passando.

Com a vida conduzida por uma cafetina, Duzu passou a ter um quarto na casa de D. Esmeraldina, para agora poder atender aos seus clientes. A personagem passa de uma menina abandonada pelos pais a uma prostituta em formação, que faz o que faz para poder ter uma casa e comida. A vida de Duzu é construída com abusos, estupros e violência.

A velha mendiga do conto revela, através das 
lembranças, o universo "natural" da mulher negra e marginalizada. Quando criança seguiu um caminho predestinado, remanescente do período escravocrata, e que ainda perpetua nas camadas mais pobres da população - o serviço doméstico, quase que reservado à mulher/menina negra: "[..] $\mathrm{Na}$ cidade havia senhoras que empregavam essas meninas". (EVARISTO, 2014, p. 32)

E quando jovem, se bonita, ao serviço sexual, onde convivem a brutalidade, a violência e a exploração:

Duzu morou ali muitos anos e de lá partiu para outras zonas. Acostumou-se aos gritos das mulheres apanhando dos homens, ao sangue das mulheres assassinadas. Acostumou-se às pancadas dos cafetões, aos mandos e desmandos das cafetinas. Habituou-se à morte como uma forma de vida. (EVARISTO, 2014, p. 34)

Pode-se considerar, assim, que a vida de Duzu foi calcada em todos os tipos de violência, seja ela física, sexual e simbólica. Além disso, o conto de Duzu apresenta a dura realidade dos marginalizados e despossuídos econômica e socialmente. Aqui, Conceição são só rompe com a estética do belo, como descreve o cotidiano miserável e escancara a sujeira e a pobreza: "Duzu lambeu os dedos gordurosos de comida, aproveitando os últimos bagos de arroz que tinham ficado presos debaixo de suas unhas sujas." (EVARISTO, 2014, p. 31). Conceição, ainda, tem a genialidade de expor a frágil relação que existe entre o centro e a periferia, entre negros e brancos, entre a cultura dominante e a do dominado: "Um homem passou e olhou para a mendiga, com asco. Ela devolveu um olhar de zombaria. O home apressou o passo, temendo que ela se levantasse e viesse lhe atrapalhar o caminho." (EVARISTO, 2014, p. 31).

É necessário apontar o espaço social que separa essas duas personagens, visto que a convivência dessas diferentes realidades é conflituosa, pois há um aparente consenso, uma não aceitação mútua do diferente, percebe-se no gesto do transeunte, a confusão entre diferença e inferioridade. Essa mesma diferença no espaço social faz com que a vida de Maria, personagem no próximo conto em análise, acabe de forma violenta e trágica. Se por um lado, a literatura canônica representava o negro por meio de uma estereotipagem, "reduzido a alguns fundamentos fixados pela natureza, a umas poucas características simplificadas" (HALL, 2016, p. 173), por outro, se vê em Evaristo (2014) a denúncia da violência contra o povo negro, em especial a mulher negra, mesmo que representada por uma estereotipagem reducionista que naturaliza e fixa o "diferente" (HALL, 2016).

De acordo com Hall (2016, p. 192), "outra característica da estereotipagem é a sua prática de fechamento e exclusão. Simbolicamente, ela fixa os limites e exclui tudo o que não the pertence". No conto "Maria", essa exclusão social é marcada pela felicidade da personagem em receber o alimento que sobrara do jantar (os restos de uma festa) de sua patroa e a indagação (talvez esperançosa) do que as crianças achariam do sabor do melão (a priori uma fruta comum, mas que nunca tinha sido oferecida aos seus filhos):

No dia anterior, no domingo, havia tido festa na casa da patroa. Ela levava para casa os restos. O osso do pernil e as frutas que tinham enfeitado a mesa. Ganhara as frutas e uma gorjeta. [...] Daria para comprar também uma lata de Toddy. As frutas estavam ótimas e havia melão. As crianças nunca tinham comido melão (EVARISTO, 2015, p. 39-40).

A segregação existente na relação patroaempregada revela uma sociedade fragmentada no que diz respeito aos direitos igualitários e à divisão econômica. Enquanto se vê Maria do outro lado da margem social, cindida de seus direitos, de suas conquistas econômicas, sociais e sentimentais, podese perceber como a estereotipagem imposta ao sujeito negro só reforça essa exclusão social, um fantasma que só se faz necessário no momento de servir ao grupo hegemônico, dada a faceta da construção de um estereótipo historicamente marcado na pele preta.

A cor da pele considerada "diferente", "exótica" - em relação ao grupo hegemônico - "implanta uma estratégia de 'cisão', que divide o normal e aceitável 
do anormal e inaceitável [...] exclui ou expele tudo o que não cabe, o que é diferente" (HALL, 2016, p. 191). O que faz colocar em xeque esse jogo perverso praticado pela sociedade racista e machista é que Maria é uma mãe batalhadora que pensa nos filhos, uma mulher que ama, mas foi abandonada por razões diversas, do mesmo modo como muitas outras mulheres brancas: "Ao entrar no ônibus, um homem levantou lá de trás, do último banco, fazendo um sinal para o trocador. Passou em silêncio, pagando a passagem dele e de Maria. Ela reconheceu o homem. Quanto tempo, que saudades! Como era difícil continuar a vida sem ele." (EVARISTO, 2015, p. 40).

Maria é vista como "anormal e inaceitável", mas ela comunga dos desejos de todo sujeito, independentemente da cor da pele e da origem de seu povo. E assim como toda mulher, Maria ama, sente saudades, mas não perde a esperança:

O homem falava, mas continuava estático, preso, fixo no banco. Cochichava com Maria as palavras, sem entretanto virar para o lado dela. Ela sabia o que o homem dizia. Ele estava dizendo de dor, de prazer, de alegria, de filho, de vida, de morte, de despedida. Do buraco-saudade do peito dele... Desta vez ele cochichou um pouquinho mais alto. Ela, ainda sem ouvir direito, adivinhou a fala dele: um abraço, um beijo, um carinho no filho. E logo após, levantou rápido sacando a arma (EVARISTO, 2016, p. 41).

Nesse sentido, fica evidente que cabe a todas as Marias o peso da escravidão que aliena e subverte a condição humana para o povo negro. Elas são consideradas "forasteiras" nessa terra "esbranquiçada" pela história, pelos homens que viam os negros como inumanos, como não pertencentes aos progressos intelectuais (DAVIS, 2016). A estereotipagem, em outras palavras, é parte da manutenção da ordem social e simbólica. Ela estabelece uma fronteira simbólica entre o "normal" e o "pervertido", o "normal" e o "patológico", o "aceitável" e o "inaceitável", o "pertencente" e o que não pertence ou é o "Outro", entre "pessoas de dentro" (insiders) e "forasteiros" (outsiders), entre nós e eles (HALL, 2016, p. 192).

Dessa forma, cabe às Marias, silenciadas pelos abusos históricos (vítimas da sua condição de mulher de pele preta e pobre), o peso da marginalização, da criminalidade imposta e/ou insinuada, da dúvida da decência e da honestidade. É novamente a estereotipagem vista como um "elemento-chave deste exercício de violência simbólica" (HALL, 2016, p. 193):

Era a primeira vez que ela via um assalto no ônibus. Imaginava o terror das pessoas. $\mathrm{O}$ comparsa do seu ex-homem passou por ela e não pediu nada. [...] Maria olhou saudosa e desesperada para o primeiro. Foi quando uma voz acordou a coragem dos demais. Alguém gritou que aquela puta safada lá da frente conhecia os assaltantes. Maria se assustou. Ela não conhecia assaltante algum. Conhecia o pai de seu primeiro filho. Conhecia o homem que tinha sido dela e que ela ainda amava tanto. Ouviu uma voz: Negra safada, vai ver que estava de coleio com os dois. Outra voz vinda lá do fundo do ônibus acrescentou: Calma, gente! Se ela estivesse junto com eles, teria descido também (EVARISTO, 2016, p. 41-42).

O que fica evidente no discurso racista "Negra safada" é a criminalização por causa de sua raça e a dúvida da honestidade ("estava de coleio com os dois"). A representação dessa identidade é marcada pela violência simbólica, pela submissão ao poder da Tradição (WITTIG, 2006), pela relação tensa existente entre a violência física e a psicológica. São cicatrizes que marcam o corpo e a alma, como o aprisionamento por meio dos grilhões e a dança do chicote que insiste em arrancar lágrimas e sangue. Entretanto, Maria não está mais na condição de escrava punida pelo feitor ou pelo capitão do mato. Talvez seja pior, Maria está na condição de escrava de sua história, de seu povo, de sua memória. Maria está presa no jogo feroz e perverso do poder. Maria é reduzida, é simplificada, é fixada a sua natureza de mulher negra, é estereotipada. Na estereotipagem, então, estabelece-se uma conexão entre representação, diferença e poder:

[...] Muitas vezes, pensamos no poder em termos de restrição ou coerção física direta, contudo, também falamos, por exemplo, do poder na representação; poder de marcar, atribuir e classificar; do poder simbólico; do poder da expulsão ritualizada. O poder, ao que parece, tem que ser entendido aqui não apenas em termos de exploração econômica 
e coerção física, mas também em termos simbólicos ou culturais mais amplos, incluindo o poder de representar alguém ou alguma coisa de certa maneira - dentro de um determinado "regime de representação" (HALL, 2016, p. 193).

Na representação da construção da identidade de Maria, percebe-se bem a conexão entre diferença e poder no processo de estereotipagem, uma vez que não cabe à mulher negra o direito de questionar os seus agressores, de se defender da culpa imputada e ela. Maria é prisioneira do ciclo do poder a quem cabe obedecer quem o detém. Não houve defesa e contraargumento. Maria é punida, é dilacerada, é fragmentada, é cindida como o que sempre coube e ainda cabe à mulher negra:

A primeira voz, a que acordou a coragem de todos, tornou-se um grito: Aquela puta, aquela negra safada estava com os ladrões! [...] Olha só, a negra ainda é atrevida, disse o homem, lascando um tapa no rosto da mulher. Alguém gritou: Lincha! Lincha! Lincha!... Uns passageiros desceram e outros voaram em direção à Maria. [...] Lincha! Lincha! Lincha! Maria punha sangue pela boca, pelo nariz e pelos ouvidos. A sacola havia arrebentado e as frutas rolavam pelo chão. Será que os meninos iam gostar de melão? [...] Quando o ônibus esvaziou, quando chegou a polícia, o corpo da mulher estava todo dilacerado, todo pisoteado. Maria queria tanto dizer ao filho que o pai havia mandado um abraço, um beijo, um carinho (EVARISTO, 2016, p. 42).

"Lincha! Lincha! Lincha!...". E Maria cedeu calada, silenciada como seus antepassados, mas um grito quis ecoar. Um grito de resistência, um grito de denúncia. Maria quis dizer ao filho "que o pai havia mandado um abraço, um beijo, um carinho". Maria gritou um basta por meio do amor. Maria gritou pelo silêncio "ensurdecedor" da escrita de Evaristo.

Já o terceiro conto analisado neste bloco é o que narra a história de Natalina, uma mulher negra que teve a vida marcada pela violência e pelos abortos cometidos. Dos quatro filhos que ela pariu, apenas com um ela desejou ficar. A primeira gravidez foi acidental aos 14 anos, com seu namorado Bilico: "Brincava gostoso quase todas as noites com seu namoradinho e quando deu fé, o jogo prazeroso brincou de pique-esconde lá dentro de sua barriga." (EVARISTO, 2014, p. 44). Esse primeiro filho, Natalina rejeitou. Tentou evita-lo de todas as formas, mas quando a mãe disse que a levaria para Sá Praxedes, uma espécie de parteira que realizava abortos, Natalina fugiu. Aqui, evidencia-se a parte da inocência da menina-mulher que ela se tornava, pois a mesma confundiu prisão de vente com gravidez e acabou tomando o chá errado. Assim, Natalina deu continuidade à gestação, mas a criança ficou com a enfermeira do hospital onde ela deu à luz, pois não fazia questão nem de conhecer o rosto do filho.

O segundo fruto de Natalina, também foi acidental, e vingou de uma relação com um trabalhador da construção civil, Tonho. A criança também foi abandonada, mesmo o pai desejando ficar com ela e com o bebê. Natalina não tinha o desejo de ser esposa, mãe, dona do lar: Ela não queria ficar com ninguém. Não queria família alguma. Não queria filho. Quando Toinzinho nasceu, ela e Tonho já haviam acertado tudo. Ela gostava dele, mas não queria ficar morando com ela. Tonho chorou muito e voltou para a terra dele, sem nunca entender a recusa de Natalina diante do que ele julgava ser o modo de uma mulher ser feliz. Uma casa, um homem, um filho... Voltou levando consigo o filho que Natalina não quis. (EVARISTO, 2014, p. 46)

"[...]diante do que ele julgava ser o modo de uma mulher ser feliz. Uma casa, um homem, um filho...", percebe-se a estereotipagem que é criada em torno da forma feliz de ser mulher, estereotipagem essa que advém do modelo patriarcal machista de séculos atrás, onde a as mulheres viviam em condições de desigualdade social em relação aos homens, culminando em distintos danos e proporções. Entre estes danos encontra-se a violência praticada contra a mulher, que ultrapassa o nível social e reflete a dominação de um grupo e a subordinação de outro. Muitas das vezes essa agressão advém do simples fato de ser mulher e pertencer a uma sociedade que condescende com o modelo patriarcal de que o homem deve exercer 
poder sobre ela (CASIQUE; FUREGATO, 2006; FERREIRA, 2010). ${ }^{1}$

O terceiro filho gerado por Natalina foi um pedido do casal para quem a jovem trabalhava. Eles viajavam muito, o que fazia com que Natalina protagonizasse pensamentos de que a casa era dela. Como o casal não conseguia ter filhos, a patroa pediu que Natalina se deitasse com seu marido para que ela engravidasse e desse a criança para eles, nos pensamentos da mulher "Natalina só tinha um tom de pele mais negro. Um filho do seu marido com Natalina poderia passar como sendo seu." (EVARISTO, 2014, p. 47). Foi a pior gravidez da personagem. Mesmo ela sendo tratada com todo zelo pelo casal, vomitou até na hora do parto, momento esse em que ela ficou entre a vida e a morte. Como a geradora não teve leite no peito e não sendo mais necessária para os patrões, logo foi demitida e esquecida por eles.

O quarto e último filho de Natalina veio depois de um sequestro, no qual os bandidos a confundiram com outra mulher, pois perguntavam para ela onde estava seu irmão. Como ela há muito já se afastara da família negou que tinha um irmão. No entanto, eles não se convenceram e ficou a cabo daquele que estava ao volante dar um fim na vida da moça. Antes, porém, ele a violentou sexualmente, e depois do gozo, em um momento de distração, deixou o revólver cair. No mesmo instante, Natalina tomou posso do revólver e matou seu violentador. Contudo, a semente desse homem já havia sido implantada em seu vente, e logo a semente germinava.

O tom de sarcasmo, nesse conto, se encontra no fato de Natalina ter desejado ficar com o filho que foi fruto de um estupro. Mesmo sendo vítima de uma violência sexual, Natalina não pensou em abortar aquele bebê e desejou ficar com ele justamente por não ter que dividi-lo com mais ninguém:

Não, dessa vez ela não devia nada a ninguém. Se aquela barriga tinha um preço, ela também tinha o seu, e tudo tinha sido feito com uma moeda bem valiosa. Agora teria um filho que seria só seu, sem ameaça de pai, de

1 CASIQUE CASIQUE, L; FUREGATO, A. R. F. Violência contra mulheres: reflexões teóricas. Rev. Latino-am Enfermagem, São Paulo, v. 14, N. 6, p. 137-144, Nov. / Dez. 2006. mãe, de Sá Praxedes, de companheiro algum ou de patrões. E haveria de ensinar para ele que a vida é viver e é morrer. É gerar e é matar. (EVARISTO, 2014, p. 49)

Nascida na pobreza e marcada pela carência de afeto e informação, a adolescente favelada tornase mãe precoce e é obrigada a entregar os filhos indesejados, tudo isso em um processo de rejeição e embrutecimento que passa até pela "barriga de aluguel" para o bebê gerado do sexo com o patrão. $O$ calvário de Natalina atinge um nível tragicamente irônico quando ela decide ficar o filho fruto de um

estupro seguido de assassinato do agressor pela vítima. A jovem foge mas "guarda a semente invasora"2 daquele homem. Ao final, Natalina constata que o filho estava para arrebentar no mundo a qualquer hora. Estava ansiosa para olhar aquele filho e não ver a marca de ninguém, talvez nem a dela. Um filho que fora concebido nos frágeis limites da vida e da morte. ${ }^{3}$

O último conto a ser analisado nesse tópico, talvez, seja o mais violento, o que mais aproxima o leitor dos sentimentos da personagem. Luamanda, mãe de cinco filhos, solteira, abandonada por todos os parceiros e parceiras, considerava-se uma mulher livre, pois ela teve vários amores, homens, mulheres, qualquer um que se dispusesse a lhe dar amor, por mais que isso durasse apenas uma noite. O único problema é que essa liberdade, esses inúmeros amores deixaram muitas cicatrizes em seu corpo e em sua alma.

A narrativa transcreve, em tons de memória, os diferentes enlaces amorosos da personagem vividos em suas quase cinco décadas de existência, perfazendo a sua conexão com a lua em momentos de gozo-prazer. Personagem recorrente em diferentes mitologias, a lua é responsável pelo movimento das marés, interfere na agricultura, e nas crenças dos povos. "Era a lua mostrar-se redonda no céu, Luamanda na terra desminliguia todinha. [...]Levava a mão ao peito e sentia a pulsação da vida

\footnotetext{
2 EVARISTO, 2014, p. 50

${ }^{3}$ EVARISTO, 2014, p. 50
} 
desenfreada, louca. Taquicardia. Tardio seria, ou mesmo haveria um tempo em que as necessidades do amor seriam todas saciadas?" (EVARISTO, 2014, p. 60-61).

Em algumas lendas de origem africana, a lua representa o princípio do feminino, está vinculado a fertilidade e os poderes ocultos do feminino. Assim, a representação da lua no conto é carregada de simbolismos míticos atrelados a uma memória ancestral negra, tema fortemente presente na escrita de mulheres negras, e que revela, já de início, uma configuração diferente sobre essa mulher e a relação de cumplicidade que ela estabelece com esse corpo. A leitura do desejo do corpo-Luamanda (a "Lua" "manda") segue as intempéries da lua: "O coração de Luamanda coçou e palpitou, embora a cara a lua nem estivesse escancarada no céu. Não fazia mal, a lua viria depois. E veio, várias vezes. Lua cúmplice de barrigas-lua de Luamanda. Vinha para demarcar 0 tempo da mulher e expulsar, em lágrimas ammnióticas e sangue, os filhos: cinco." (EVARISTO, 2014, p. 61)

A relação estabelecida entre a protagonista e a lua dá o tom da narrativa: assim como a lua, a mulher desdobra-se em faces. E o seu corpo reflete um discurso de ancestralidade, recuperando o mitológico de perspectiva afrocentrada, tema recorrente na literatura de Conceição. O corpo-lua segue uma lógica diferente da perspectiva ocidental tanto de tempo quanto de compreensão dos desejos do corpo da mulher. As luas cúmplices dos seus gozos são também luas que marcam o início e o fim do período de gestação no "buraco-céu aberto no seu corpo" (EVARISTO, 2014, p.61).

Enquanto uma tradição cristão-ocidental criou uma narrativa do pecado, o corpo em Luamanda representa a comunhão da personagem com 0 mundo a sua volta, e isso é desenhado com um olhar positivo. Recobrando os discursos hegemônicos construídos sobre os corpos das mulheres negras, observamos que a sexualidade dessas mulheres foi redimensionada para caber nos estereótipos racistas: seu corpo, enquanto produto para satisfação do outro, não representava um espaço de escolha. Enquanto as representações hegemônicas falam da mulher negra como objeto de prazer do homem branco, cheia de lascívia, o conto de Evaristo revela uma mulher sujeito do seu corpo:

Segundo Alves (2010, p.70-71), em Mulheres negras: vozes na literatura, a palavra de ordem na escrita literária feminina afrobrasileira é que os seus corpos lhes "pertencem". Corpos femininos negros "vitimizados", que necessitam, antes de tudo, liberar-se do "confinamento do silêncio", onde foram incluídos e excluídos pelas "amarras" ideológicas construídas pela dominação masculina. Corpos femininos negros que guardam desejos contidos e que ambicionam se "desvencilhar das marcas de sexualização e da racialização neles inscritas" sem se esquecer de outras necessidades. (SALES, 2011, p. 81)

Como sinalizado por Sales (2011), o corpo da mulher negra, na literatura afro-feminina, ganha uma textualidade poética que rompe com a imagem da hipersexualidade destinada a esses sujeitos, traços vinculada a procedimentos racistas e sexistas imputados a mulheres negras. O texto acompanha o percurso da personagem por suas histórias de amor, partilhadas com outros corpos e as possibilidades que esses encontros puderam proporcionar. Assim, a personagem descobre e se questiona sobre o amor em suas diferentes formas: entendido como prazer do sexo, mas também numa compreensão de afetividade: um eco ao final de cada ciclo amoroso da personagem, ela se pergunta: "O amor é terremoto? [...] O amor cabe em um corpo? [...] o amor é um tempo de paciência?" (EVARISTO, 2014, p. 60-62).

Assim, o corpo-afeto de Luamanda respira indagações não normativas ou simplistas, mas cobertas de significados outros: o que é o amor para ela. Observa-se o tema do amor sempre foi caro às mulheres negras, pois essas sempre foram nãosujeitos das relações afetivas. Retomando Sales (2011, p. 81): "Corpos femininos negros que falam de amor à vida e do amor ao outro, do erotismo, da identidade feminina, do sentir-se mulher negra e do sentido da própria existência em uma sociedade racista e sexista". No decorrer da narrativa, acompanham-se seus primeiros gozos, suas paixões, 
as barrigas-luas, sua maturidade, o ápice de seu encontro com um igual corpo:

Depois, tempos depois, Luamanda experimentava 0 amor em braços semelhantes aos seus: [...]E quando se sentiu coberta por pele, poros e pelos semelhantes aos seus, quando a sua igual dançou com leveza a dança-amor com ela, saudade alguma sentiu, vazio algum existiu, pois todas as fendas do seu corpo foram fundidas nas femininas oferendas da outra."(EVARISTO, $p$. 2014, p.61)

Luamanda, uma mulher autoconsciente do seu corpo e das belezas que ele podia proporcionar, debate o signo da sexualidade negra. Construída sob a representação exclusiva da heterossexualidade, a imagem da mulher, quando não era ignorada, era destituída de outras vivências sexuais. A personagem relata a tensão pelo medo da falta do falo, contudo, no envolvimento dos corpos, revela-se que nada falta. Esse discurso denuncia a perspectiva falocêntroica da sexualidade normativa, pois, a necessidade do falo é o que constitui nessas narrativas a atividade sexual.

O narrador, aqui, descontrói a representação fantasiosa do imaginário sobre as experiências sexuais entre mulheres. A narrativa contrapõe um discurso que prega padrões fixos de sexualidade. Ela coloca em debate a uma norma da sexualidade (e afetividade) que impõe identidades fixas e que seriam determinadas por práticas sexuais. Assim, Luamanda, mulher, encontra gozos-luas em corpos distintos e iguais aos seus.

No decorrer do texto, outros corpos encontram o corpo-lua da protagonista, e as suas experiências revelaram a descoberta dos próprios prazeres: "Todos foram os amores da vida de Luamanda, que sempre chamava mais um." (EVARISTO, 2014, p. 62). Apesar de ser tão livre e ter tantos amores, a protagonista também teve o corpo e a alma marcados por atitudes violentas. Aqui se apresenta a cena mais forte e dolorosa do conto:

Se havia o amor na vida de Luamanda, também um grande fardo de dor compunha as lembranças de seu caminho. A vagina ensanguentada, perfurada, violada por um fino espeto, arma covarde de um desesperado homem, que não soubera entender a solidão da hora da partida. E durante meses, o sangue menstrual de Luamanda, sangue de mulher que nasce naturalmente de seu úteroalma vinha misturar-se ao sangue e pus, dádivas dolorosas que ela ganhara de um estranho fim amoroso. E pior do que a dor foi a dormência de que foi atacada, em sua parte tão viva, durantes meses a fio. (EVARISTO, 2014, p. 62)

A protagonista é violada por um homem que não aceita o término do relacionamento e precisa cuidar do corpo e aprender, com paciência, aguardar o tempo da cura: "Foi um tempo em que precisou exercitar a paciência com o seu próprio corpo. Trancada em si, ou melhor, aberta para si mesmo, com as mãos espalmadas e leves imaginava lenitivos carinhos." (EVARISTO, 2014, p. 63)

Nesse sentido, compreende-se que o homem se sente dominador e expressa violência em relação à mulher porque, segundo Rosiska Darcy de Oliveira, por muito tempo as mulheres foram consideradas como um ser inferior, pois a

[...] cultura masculina alimentou representações das mulheres como seres anfíbios, mais instintuais que os homens: alheias à Razão, rebeldes à domesticação [...]. Naturalizadas, as mulheres não foram incorporadas ou tornadas significativas na cultura humana/masculina. O confinamento do sexo feminino em uma relação limitada com apenas alguns aspectos do meio ambiente [...] traduziu-se em desigualdade de status e poder, tornando-se hierarquia que [...] passou a ser percebida como um dado do comportamento humano, inscrita no corpo e por ele ditado, e que as representações mitológicas e ideológicas só fizeram confirmar (OLIVEIRA, 1999, p.40).

Assim, sendo as mulheres seres inferiores, os homens acharam-se no direito de dominá-las e maltratá-las. Eva Blay afirma que "agredir, matar, estuprar uma mulher ou uma menina são fatos que têm acontecido ao longo da história em praticamente todos os países [...]" (BLAY, 2003, p. 87). Essa cultura masculina dominante acabou deixando cicatrizes no corpo e na alma de Luamanda, cicatrizes que marcam a vida de tantas mulheres pelo mundo. 


\section{Conclusões}

A partir do exposto até aqui, evocando um diálogo com as representações da tradição hegemônica, conclui-se que Evaristo provoca uma discussão sobre os sentidos afixados historicamente à sexualidade da mulher negra e põe em debate a literatura negra/afro-brasileira como espaço de subversão e resistência. Entende-se, portanto, que ao deixar florescer uma iconografia negra, autores e autoras negras constroem novos modelos representativos e o [re]conhecimento das identidades negras. Por isso a necessidade de autoras como Conceição e trabalhos que deem visibilidade a essas autoras e as temáticas levantadas por elas.

Mesmo sabendo que a violência se perpetua ao longo dos tempos e a mulher, por apresentar uma maior fragilidade corporal é sua principal vítima, é fundamental estudos que dialoguem sobre a violência de gênero. Sabe-se, que desde a mitologia Grecoromana o homem se configura como herói e a mulher como a origem do mal, causadora da tentação masculina.

Tal fato é apontado até na história da humanidade onde o livro de gênese traz a figura de Eva como uma sedutora, levando Adão a cometer o pecado, demarcando a mulher como pecadora que deve ser por conta de seus atos, submissa ao homem, Ihe devendo obediência (SANTOS, 2011)4. É nesse contexto que se faz mais necessário uma luta feminina que desmistifique a teoria falocêntrica e coloque a mulher como sujeito ativo e insubmisso em uma sociedade até então calcada em ideologias patriarcais.

\section{Referências}

BOURDIEU, P. A dominação masculina. 13. ed. Rio de Janeiro: Bertrand Brasil, 2005.

BUTLER, J. "Sujeitos do sexo/gênero/desejo". In: Problemas de gênero: Feminismo e subversão da identidade. Rio de Janeiro: Civilização Brasileira, $2003 . \quad$ Disponível em: http://minhateca.com.br/Angela.Rojo/Galeria/ART ES/BUTLER ${ }^{\star} 2 \mathrm{c}+$ Judith.+Problemas+de+Genero+ 1-2,15243929.pdf>. Acesso em 24 set. 2019.

CHAUÍ, M. Participando do debate sobre Mulher e Violência. In.: FRANCHETTO, Bruna, CAVALCANTI, Maria Laura V. C. e HEILBORN, Maria Luiza (org.). Perspectivas Antropológicas da Mulher 4. São Paulo, Zahar Editores, 1985.

DAVIS, A. Mulheres, raça e classe. Trad. Heci Regina Candiani. São Paulo: Boitempo, 2016.

DUARTE, C. L. "Pequena história do feminismo no Brasil”. In: CARDOSO, Ana Leal; GOMES, Carlos Magno. Do imaginário às representações na literatura. São Cristóvão: Ed UFS, 2007.

Gênero e violência na literatura afro-brasileira. In: ALEXANDRE, Marcos Antônio; DUARTE, Constância Lima; DUARTE, Eduardo de Assis (orgs.). Falas do outro - literatura, gênero, etnicidade. Belo Horizonte: Nandyala; NEIA, 2010. pp. 229-234.

DUARTE, E. A (Org.). Literatura e afrodescendência no Brasil: antologia crítica. Belo Horizonte: Ed. UFMG, 2011. vol. 1, 2 e 3.

Mulheres marcadas: literatura, gênero e etnicidade, 2009. Belo Horizonte, Scripta: v. 13, n.25. Disponível em: $<$ http://periodicos.pucminas.br/index.php/scripta/ar ticle/viewFile/4368/4513 >. Acesso em: 20 de set. 2018.

ESMERALDA RIBEIRO E MÁRCIO BARBOSA. Esmeralda Ribeiro. Quilombhoje. 2015. Disponível em: $\quad<$ http://www.quilombhoje.com.br/site/>. Acesso em: 02 set. 2018.

EVARISTO, Conceição. Olhos D'água. Rio de Janeiro: Pallas: Fundação Biblioteca Nacional, 2014. 116p.

GOMES, C.M. Marcas da violência contra a mulher na literatura. Revista Diadorim, UFRJ, Rio de Janeiro. Volume 13, Jul. 2013. Disponível em: $<$ http://www.revistadiadorim.letras.ufrj.br/index.php /revistadiadorim/article/viewFile/290/252>. Acesso em: 30 set. 2018 .

\footnotetext{
4 SANTOS, J. T. Violência contra a mulher nos espaços urbanos da cidade de Manaus (AM): dois anos antes e dois anos depois da lei Maria da Penha. 2011. $141 \mathrm{f}$. Mestrado em Geografia Humana. Universidade de São Paulo, São Paulo. 2011.
} 
HALL, S. A identidade cultural na pós-modernidade. Trad. Thomas Tadeu da Silva e Guacira Lopes Louro. 11. Ed. Rio de Janeiro: DP\&A, 2006.

Cultura e representação. Trad. Daniel Miranda e William Oliveira. Rio de Janeiro: Ed. PUC-Rio: Apicuri, 2016.

OLIVEIRA, E. R. Violência doméstica e familiar contra a mulher: um cenário de subjugação do gênero feminino. Rev. LEVS/UNESP, Marília, 9ª Ed, Mai. 2012.

OLIVEIRA, R.M.R de. Para uma razão crítica da razão androcêntrica: gênero, homoerotismo e exclusão da ciência jurídica. Caderno Themis: Gênero e Direito, Porto Alegre (RS), v. 3, n. 3, 2002 Disponível em: <https://periodicos.ufsc.br/index.php/sequencia/arti cle/view/15232/13852>. Acesso em 25 set. 2019

RAGO, M. Epistemologia feminista, gênero e história. In: PEDRO, Joana; GROSSI, Miriam (org). Masculino, Feminino e Plural. Florianópolis, Ed. Mulheres, 1998. Disponível em: < http://projcnpq.mpbnet.com.br/textos/epistemologi a_feminista.pdf > Acesso em 15 fev. 2018.
SALES, C.S. de. Composições e recomposições: o corpo feminino negro na poesia de Mirian Alves. 2011. 125f. Dissertação de mestradoUniversidade Estadual da Bahia, Salvador, 2011.

SAFFIOTI, H. I. B. Gênero, Patriarcado, Violência. São Paulo, Editora Fundação Perseu Abramo, 2004.

Moderna, 1987.

O Poder do Macho. São Paulo,

Violência de gênero: poder e impotência. Revinter, Rio de Janeiro, 2000.

A Mulher na Sociedade de Classes: Mito e Realidade. Petrópolis, Editora Vozes, 1976.

SANTOS, J. T. Violência contra a mulher nos espaços urbanos da cidade de Manaus (AM): dois anos antes e dois anos depois da lei Maria da Penha. 2011. 141 f. Mestrado em Geografia Humana. Universidade de São Paulo, São Paulo. 2011.

TIBURI, M. Feminismo em comum: para todas, todes e todos. 4. ed., Rio de Janeiro: Rosa dos Tempos, 2018.

\section{COMO CITAR ESSE ARTIGO}

PAIM, Luciane de Lima; FERREIRA, Patrini Viero; UMBACH, Rosani Úrsula Ketzer. Por entre lágrimas e rastros de sangue: as dores e angústias representadas pela violência contra a mulher em olhos d'água, de Conceição Evaristo. Signo, Santa Cruz do Sul, v. 45, n. 82, jan. 2020. ISSN 1982-2014. Disponível em: $<$ https://online.unisc.br/seer/index.php/signo/article/view/14360>. Acesso em: doi:https://doi.org/10.17058/signo.v45i82.14360. 